\title{
THE ANALYSIS OF CAUSAL FACTOR ON STUDENT SPEAKING ANXIETY
}

\author{
Dedy Subandowo \\ Muhammadiyah University of Metro, Indonesia \\ dedy.subandowo@pbiummetro.ac.id
}

\begin{abstract}
This article examines the analysis of causal factor on student speaking anxiety. This study is to explain what factors affecting the students speaking anxiety. Moreover, the research data are taken from the second semester students of English Education Study Program, Muhammadiyah University of Metro. This is a descriptive qualitative study and some instruments such as documentation, interview, observation are used in order to collect the data. The data is then analyzed by some steps, like data collection in which writer gathers all of the data that will be used to complete the research. After collecting the data, the writer sorts the data by summarizing and choosing the specific category, displaying the data, verifying the data analysis, and making a conclusion from the finding data. The result of this research shows the students speaking anxiety causal factors in the second semester. Most of the students feel anxious when speaking English in the class. Eventually, some suggestions are discussed in order to help students reduce anxiety and become more confident to speak English in oral language classrooms.
\end{abstract}

Keywords: analysis study, causal factors, speaking anxiety, speaking skill

\section{INTRODUCTION}

English as one of the languages has an important role in this world (Genç \& Bada, 2010). It is as one of the international languages in the world (Fang \& Baker, 2017). Most of the people in some different countries use English to communicate in some aspects of life such as politics, economics, culture, education, social, etc. Therefore, it has been considered as the way to express the ideas and other feelings of communicative expression such as oral or writing. In this case, the categorization of oral language would be crucial to explore because of regarding the government rules that English has been applied to all levels of education and institution as the curriculum in order to prepare the students to be skillful at using English. Not to mention that university students are also taking into account in building their confidence in speaking English especially for the students of English department (Nunan, 2003).

There is an important problem faced by the students in learning English, particularly in speaking part. Some students express their inability and sometimes they show their failure in speaking English. They may be good at learning other skills but when it comes to English, they claim that they feel afraid to speak English (Basic, 2011). Therefore, students' feeling of anxiety or nervous may impede their language learning and performance abilities, especially when practice speaking English in speaking class (Akkakoson, 2016).

\section{LITERATURE REVIEW}

The study of speaking anxiety was conducted by Zhiash Suleimenova was focusing on foreign language classroom in Kazakhstan (Suleimenova, 2013). The main purpose of the research is to find out whether the EFL learners feel anxious or embarrassed while learning to speak English and what the consequences of students 
are reported. The research revealed that there are some factors influencing the students' speaking anxiety like they become stressful in some situations. What is more, this study gives some solution that could be tackled by the teacher to reduce and help the students from that of the factor when speaking English in the English Foreign Language class.

On the other hand, the research discussing the language speaking was also published by Meihua Liu entitled "anxiety in oral English classrooms (a case study in China)" (Liu, 2007). This research was taken at Department of Foreign LanguagesTsinghua University, Beijing. The research revealed that: 1) anxiety was experienced by a considerable number of students when speaking English in class. 2) The students reported being the most anxious when singled out to speak English in class or giving presentations at the front while the least during pair work. 3) A multitude of variables such as lack of vocabulary, low English proficiency, and memory disassociation contributed to student anxiety in class 4.) Most students felt helpless about being anxious when speaking English in class.

a. Definition of Speaking

Speaking could be defined as the medium of human communication and to express ideas, feeling, thought and need orally (Peters, 2012). According to (Thombury, 2005)"Speaking has become a part of daily life". Another side, "Speaking is an interactive process of constructing meaning that involves producing, receiving, and processing information. Hence, that "speaking is to say words, to talk, say or mention something, to know and to be able to use the language". By all means, speaking does matters not only giving the interaction and using the language to express the ideas, feeling and thought, but sharing the information with others through communication as well (Ruesch, 2017).

Similarly, another argument stated that speaking skill means able to communicate using the English pattern base on the situation when the peoples need to utterance their thoughts, feels, and ideas (Yambay, 2017), (Kurniati, 2017). Speaking is also more difficult to be mastered than other language use (reading, writing, and listening) (Purpura, 2017). Such as (Nunan D., 2003) confirms that many people feel that speaking is harder to be learning than reading, writing and listening. Then, he states these two reasons: 1) Speaking happens in real time, unlike reading or writing. Real time here means that when your partner speaks with you, he/she usually waits for your response at that time. 2)You cannot type or correct what you say when you are speaking, unlike in writing, you can retype or revise your words. It can be concluded that speaking activities increase the level of anxiety because during speaking the learners of the foreign language have to interact with other people and when speaking spontaneously done by speaker and responder.

b. Speaking Anxiety

In some cases, speaking anxiety could be associated with a feeling of uneasiness, frustration, self-doubt, apprehension, or worry (Finnema, 2017). This might bring negative influences for students in learning and teaching process, especially when speaking English. Besides, anxiety is one of most negatively influential affective variables, which prevents learners from successfully learning a foreign language. (Greenberg, 2017)states that "anxiety is feelings of discomfort that people experience before, during, and after speaking in public". The basis of the statement is when the students feel anxious, student discomfort and not confident to speak in front of the class and anxiety makes the language learners nervous and afraid, which may contribute to poor oral performance (Morris, 2017). 
c. The Causes of Speaking Anxiety

(Liu, 2007) stated that speaking anxiety is caused by some factors such as lack of vocabulary, low English proficiency, lack of preparation, lack of practice, fear of making mistakes and being laughed at, fear of losing face, fear of being the focus of attention, Inability to express ideas, memory dissociation. Meanwhile, (Kanar, 2013) mentioned some strategies to reduce anxiety for many students namely positive self-talk, relaxation, and visualization. Referring to the statements above, (Dornyei, 2001) stated that self-confidence is social products, which means that they are created and shaped by the people around us. On the other hand, the surrounding environment has the important role to reduce anxiety. Therefore, the opinion of significant figures, or someone around us such as the teacher, plays an important role in reinforcing (or reducing) anxiety and brings motivational strategies in the language classroom self-image.

\section{METHODS}

This research uses analysis study in which the case study is conducted for whole the experiment. Likewise, the descriptive qualitative would be suitable to elaborate the analysis. This means the researcher makes an interpretation of the data. This includes developing a description of an individual or setting, analyzing data for themes or categories, and finally making an interpretation or drawing conclusions about its meaning personally and theoretically (Creswell, 2013). Moreover, a qualitative study has a strong correlation with activities and behaviors with human groups (Travers, 2001 ).

The subject of this research was the second-semester students of English education study program, Muhammadiyah University of Metro. There are more than 35 students participating in this study. Nevertheless, the researcher only chose ten students randomly in order to analyze the speaking anxiety. On the other hand, the documentation like student's performance and daily score have collected as the secondary data. Furthermore, a depth interview and class observation are used in this research to complete the data collection.

\section{FINDINGS AND DISCUSSION}

\subsection{Findings}

Generally, there are two factors affecting the students speaking anxiety. They are the internal and external factor. The internal factors contain limited vocabulary and low English proficiency, less practicing and preparation, fear of losing face, inability to express the idea. While the external factors are being afraid of making mistake, and focus attention.

4.2 Discussion

a. Internal factors

1) Lack of vocabulary and low English proficiency

Statements like "my oral English is poor, and so when I want to speak it to somebody, I am always nervous", it probably causes them have no confidence in speaking English in front of the class. The data showed that most factor influencing the students are having a lack of vocabulary when speaking English in front of the class.

Question : How is your vocabulary mastery in speaking English?

Student $\mathrm{H} \quad$ : I never memorize the vocab (saya gak pernah ngafal vocab, kalo mau maju kedepan ya diapalin apa yang mau diomongin aja. Kalo gak ngerti bisa lihat kamus) 
2) Lack of preparation and lack of practice

Lack of practice and preparation is the another problem when the students perform they're speaking English in front of the class. They should practice more to reduce this problem. The percentage showed that $40 \%$ of the students' did practicing and preparing before their performance. Preparation is the important thing to do before performing the action. The students will be worried to make a mistake or forget something if they do not prepare themselves.

3) Fear of losing face

Fear of losing face is similar with ashamed of something. This is one of the factors that makes the students felt anxious. The data depicted that the students of English education study program are afraid of losing face or ashamed of something. The percentage is almost $100 \%$ of the students' fear of losing face.

Student A : when the teacher asking me about many problems and then I cannot answer the question clearly, that make me ashamed in front of my friend and because I don't have many vocabularies so I can't speak English fluently.

4) Memory dissociation

Some students became nervous when speaking English in front of the class because they are difficult to memorize what they have already learned or prepared. The data showed that 2 students admitted that they have memory dissociation but could also manage their anxiousness.

Question : When you are speaking in front of the class, did you forget to say what you are thinking?

Student D : yes I ever did, and it makes me nervous to continue my speaking.

Student G : yes I did, but I can manage it. For example, I've forgotten what I want to say or I forget about the vocabulary, then I change that ward I was forgotten by another word, or I say it by my own language.

5) Inability to express idea

Inability to express ideas is another cause for student anxiety in speaking English classrooms. They are afraid of talking to others. They usually have no idea how to express their meanings. This is the chart that shows the percentage of the students who inability to express their idea:

Chart 1: Percentage of the Students Inability to Express Idea

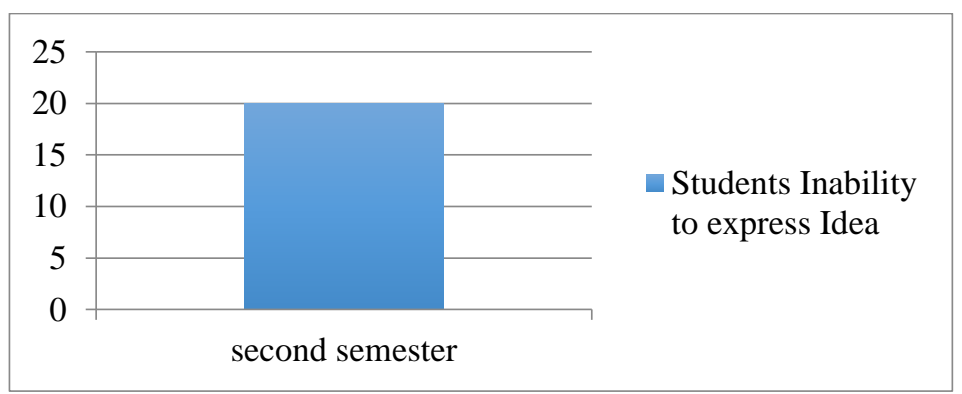

The chart illustrates that $20 \%$ of the students in the second semester is the inability to express their idea, it because some reason such as they limited vocabulary to support their English and less prepared before their performance. This result of the interview shows the data:

Question: What is your difficulty in speaking the English language? 
(The difficulty when I am speaking English is because I haven't much vocabulary to explore my idea, and I 'am afraid when I 'am making mistake).

b. External Factors

1) Fear of making mistake and being laughed at

In a language class, fear of making mistake is so strong in some students that are practically determined to stay silent rather than risk committing grammatical error (Dornyei, Z., 2001). They are fearful of making mistakes in front of the class, such as in pronunciation or grammar.

2) Fear of being focus of attention

Although many students started to learn spoken English in secondary schools, they did not have much practice at that time because of the strongly didactic nature of teaching and exam-orientedness of schooling. Consequently, many students feared to be the focus of attention and thus became anxious when singled out to speak English in front of the class. The percentage is around 30\% of the students admitted that they fear of making mistake, and fear being a focus of attention. Although many students have begun to learn oral English in high school, they do not practice much at that time because of the nature of teaching and examinations from school. As a result, many students are afraid of being the focus of attention and thus become anxious when they are chosen to speak English in the classroom (Liu, 2007).

\section{CONCLUSION}

The students felt this anxiety when they speak in front of the class. The students face the obstacle in these factors that could raise the level of anxiety: 1) inability to pronounce strange sound and word 2) not knowing the meaning of words or sentence 3 ) inability to understand and answer question 4) not knowing or understanding course goals or requirement 5) testing especially oral testing.

On the other hand, the students of the second semester were admitted that there is another factor influencing their speaking apart from the previous factors like the motivation of the lecturer and their environment. Their background of their study gives some impact for their speaking performance. The students also stated that they are increasingly accustomed to speaking English in front of the class. Likewise, it could reduce their anxiousness.

Then the students should know how to reduce speaking anxiety in front of the class and they can improve their performance, and the teacher should help the students because of the teacher has the important rule to the students. The lecturers should make teaching learning process fun, give positive feedback, motivate their students, help their student to accept the fact that will make mistake as part of the learning process, and the lecturer should speak English well and easy to understand.

\section{REFERENCES}

Akkakoson, S. (2016). Speaking Anxiety In English Conversation Classrooms Among Thai Students. Malaysian Journal of Learning and Instruction, $13,63-82$.

Basic, L. (2011). Speaking anxiety: An obstacle to second language learning?.

Creswell, J. W. (2013). Research design: Qualitative, quantitative, and mixed methods approach. California: Sage publications. 
Dornyei, Z. (2001). Motivational Strategies in the Language Classroom. London: Cambridge University Press.

Fang, F., \& Baker, ,. W. (2017). A more inclusive mind towards the world': English language teaching and study abroad in China from intercultural citizenship and English as a lingua franca perspectives. Language Teaching Research.

Finnema, E. v. (2017). Psychosocial Interventions. . In Dementia in Nursing Homes , 29-53.

Genç, B., \& Bada, E. (2010). English as a world language in academic writing. , . Reading 10(2), 142-151.

Greenberg, L. S. (2017). Emotion-focused therapy of depression. PersonCentered \& Experiential Psychotherapies, 1-12.

Kanar, C. C. (2013). The Confident Student. Wadswort: Cengage Learning seventh edition.

Kurniati, E. (2017). An Analysis On Students'learning Strategies In English Speaking Class At The Second Semester Of Batanghari University Academic Year 2015/2016., (Pp. In Proceedings (Vol. 1, No. 1).).

Liu, M. (2007). Anxiety In Oral English Classrooms: A Case Study In China. Indonesian Journal Of English Language Teaching Volume 3 Number 1, 12.

Morris, A. L. (2017). A Qualitative Exploration of the Lived Experiences of Patients Before and After Ileostomy Creation as a Result of Surgical Management for Crohn's Disease. OSTOMY WOUND MANAGEMENT, 63(1), 34-39.

Nunan, D. (2003). Practical English Language First Edition. New York: Mcg raw-hill.

Nunan, D. (2003). The impact of English as a global language on educational policies and practices in the Asia-Pacific Region. TESOL quarterly, 37(4), 589-613.

Peters, J. D. (2012). Speaking into the Air: A History of the Idea of Communication. London: University of Chicago Press.

Purpura, J. E. (2017). Assessing meaning. Language Testing and Assessment, 33-61.

Ruesch, J. (2017). Communication: The social matrix of psychiatry. Routledge.

Suleimenova, Z. (2013). Speaking anxiety in a foreign language classroom in Kazakhstan. Procedia-Social and Behavioral Sciences, 93, , 1860-1868.

Thombury, S. (2005). How to Teach Speaking. Pearson Education Limited.

Travers, M. (2001 ). Qualitative Research through Case Studies. London: SAGE.

Yambay, V. V. (2017). Exploration of the use of Task Based Learning Approach and their advantages in Speaking development, in students of the tenth year" an" of basic education at" Amelia Gallegos Díaz" high school during. Bachelor's thesis, Rabba, Unach 2017. 